\title{
LOCALIZATION OF SUPEROXIDE DISMUTASE IN THE OVARY AND UTERUS OF MICE DURING PREGNANCY WITH SPECIAL REFERENCE TO STEROIDOGENESIS AND IMPLANTATION
}

\author{
Malini LALORAYA, G. Pradeep KUMAR, Manish NIVSARKaR \\ and Manmohan M. LALORAYA* \\ School of life Sciences, Devi Ahilya Vishwavidyalaya, Vigyan Bhawn, Khandwa Road, \\ Indore 452 001, M.P., India, and Ravi Shankar University*, \\ Raipur 492 002, M.P., India
}

Received for publication January 26, 1990 and in revised form April 2, 1990

\begin{abstract}
The distribution of the enzyme $\mathrm{Cu}-\mathrm{Zn}$ superoxide dismutase in the ovary and uterus during early pregnancy has been dealt with in this histochemical study. $\mathrm{Cu}-\mathrm{Zn}$ superoxide dismutase is found to be present in membrana granulosa of Graafian follicles and ovulated follicles, corpora lutea and blood vessels of the ovary. This presence has been attributed a functional significance in the process of luteal steroidogenesis. The marked low levels of uterine $\mathrm{Cu}-\mathrm{Zn}$ superoxide dismutase and its noticeable absence in the endometrium, the site of blastocyst attachment, at 5.00 A.M. on Day 5 of pregnancy is evident. The possible involvement of these lowered levels in implantation is discussed.
\end{abstract}

The well-vascularized luteal cells present in the ovary and the allantochorionic placent-the secretory sites of progesterone have been shown to possess intense peroxidase activity during early pregnancy (2). This observation, together with the marked absence of peroxidase activity in the growing follicles or interstitial gland tissues has strengthened the earlier suggestion of the involvement of peroxidase in luteal steroidogenesis (1). The peroxidase-mediated reactions are manifold faster than dehydrogenase reactions, which justifies the suggestion that the elevated steroidogenesis during luteinization is peroxidase-mediated. The uteri of pregnant rats have also been shown to exhibit a high peroxidase activity in its well-developed decidua, the entire length of decidua being deeply stained and the endometrium exhibiting maximum localization (2). This had lead to the suggestion of the involvement of peroxidase in regulating the adhesiveness of the deciduoma for the attachment of the blastocyst (3). Thus, once the involvement of peroxidase in the luteal steroidogenesis and implantation process is invoked, it was of interest to look into the mechanism through which the living cells can generate hydrogen peroxide, which is the substrate for all peroxidase-mediated reactions in vivo. We have recently shown the changes in the levels of superoxide dismutase and superoxide anion radical during

Address for correspondence: Ms. Malini Laloraya, Endocrinology Laboratory, School of Life Sciences, Devi Ahilya Vishwavidyalaya, Vigyan Bhawan, Khandwa Road, Indore 452 001, M.P., INDIA. 
pregnancy. The high levels of superoxide dismutase in the ovary have been interpreted in terms of generation of $\mathrm{H}_{2} \mathrm{O}_{2}$ for peroxidase action so as to generate progesterone which is required in the control of extended luteal steroidogenesis during early pregnancy. The extremely high superoxide dismutase of the uterus is interpreted to be responsible for keeping the superoxide radical levels low during early pregnancy except at implantation when superoxide radical levels increase. This has been suggested to mediate implantation and the increase in vascular permeability at the time of implantation (6). Looking to these results, it would be of interest to locate the site of enzyme activity, which is achieved employing a histochemical approach.

\section{MATERIALS AND METHODS}

Animals. Sexually mature virgin female Mus musculus (Swiss strain, 3-5 months) housed in temperature-controlled $\left(27 \pm 1^{\circ} \mathrm{C}\right)$ room at light:dark regimen of $14 \mathrm{hr}: 10 \mathrm{hr}$ and provided with food and water ad libitum were used for the studies.

Reagents. Nitroblue tetrazoium, riboflavin and diethyldithiocarbamic acid were obtained from Sigma Chemical Company Inc., USA. All other reagents used were of reagent grade.

Protocol. Only those female mice which showed a regular 4- or 5-day estrous cycle were used. Vaginal smears were examined daily (9) and only those mice which showed a proestrous smear were mated with a male of proven fertility, the same evening. The presence of a vaginal plug the following morning confirmed mating. This day was designated as Day 1 of pregnancy, and the day of proestrous as Day 0. The pregnant females were decapitated at different days of pregnancy, viz., day $0,1,2,3,4,5$ and 6 . The ovaries and the uteri were removed immediately after death and freed of adhering fat. They were rinsed several times with chilled saline $(0.154 \mathrm{M}-\mathrm{NaCl})$ to wash out blood and were subsequently deep-frozen. $8 \mu \mathrm{m}$ thick cryostat sections were cut with an American Optical Cryo-cut Microtome at a cabinet temperature of $-20^{\circ} \mathrm{C}$. The sections were picked onto clean glass slides coated with Mayer's albumin adhesive and air-dried. For each stage, 3 mice were killed, both the ovaries/uteri sectioned and five sections from each ovary/uterus were studied. The same number of replicates were used for control preparations. The sections were subjected to the histochemical assay for superoxide dismutase (7). The sections were treated with $2.45 \times 10^{-3} \mathrm{M}$ nitroblue tetrazolium for $30 \mathrm{~min}$. They were later incubated in a solution containing $0.036 \mathrm{M}$-potassium phosphate $(\mathrm{pH} 7.8), 0.028 \mathrm{M}$ tetramethyl ethylene diamine and $2.8 \times 10^{-5} \mathrm{M}$-riboflavin for $30 \mathrm{~min}$. The sections were then illuminated for $30 \mathrm{~min}$ (in this time maximum contrast between achromatic regions and the general blue color was achieved) by a $15 \mathrm{~W}$ fluorescent lamp. During illumination, the sections turned blue except at sites containing superoxide dismutase. Control sections were incubated in an incubation medium which also contained diethyldithiocarbamic acid, an inhibitor of $\mathrm{Cu}-\mathrm{Zn}$ superoxide dismutase, in a final concentration of $1 \times 10^{-3} \mathrm{M}$ along with the above mentioned components. All the above photoinduced reactions were performed in a dark room using an aluminum foil-lined box fitted with a $15 \mathrm{~W}$ fluorescent lamp. The sections were rinsed once for $30 \mathrm{sec}$ in $0.036 \mathrm{M}$-potassium phosphate $(\mathrm{pH} \mathrm{7.8)}$ after illumination and then in double-distilled water. The sections were mounted in glycerol jelly and observed under a Nikon Optiphot Microscope under phase contrast optics. 
Photographs were taken using ORWO NP22 (ASA 125) black and white film. Exposure time was computed by Nikon UFX II camera monitor unit and the film was processed using fine grain developer and Amfix fixer (M \& B, India).

\section{RESULTS}

The site of enzymic activity is revealed as achromatic regions by this negative staining method. In the presence of superoxide dismutase the superoxide radical generated by illumination of riboflavin is intercepted by the enzyme and is thus made unavailable to the electron acceptor 'nitroblue tetrazolium', thus inhibiting the formation of blue formazan. The control sections, where $\mathrm{Cu}-\mathrm{Zn}$ superoxide dismutase is inhibited by diethyldithiocarbamic acid, reveal deep blue staining of all the tissue sites due to reduced nitroblue tetrazolium. High enzymic activity was exhibited by the ovaries from animals at day 0,1, 2, 3, 4, 5 (5:00 AM), 5 and 6 of pregnancy (Figs. 1a, c, e, g; Figs. 2a, c, e, g). The growing follicles, ovulated follicles and the membrana granulosa of the pre-ovulatory Graafian follicles exhibited intense enzymic activity as is clear from their achromatic nature. The walls of the blood vessels also show a high amount of superoxide dismutase. The corpora lutea and the thecal cells show lowered enzymic activity, while interstitial gland tissue is devoid of the enzyme. The achromatic zones denoting the localization of superoxide dismutase developed a deep blue color in the corresponding control sections which were treated with diethyldithiocarbamic acid (Figs. 1b, d, f, h; Figs. 2b, d, f, h).

In the uterus, $\mathrm{Cu}-\mathrm{Zn}$ superoxide dismutase is present in detectable amounts in the entire tissue obtained from animals at day 0, 1, 2, 3, 4, 5 and 6 (Figs. 3a, c, e, g; Figs. $4 \mathrm{a}, \mathrm{c}, \mathrm{g}$ ). It was observed that during day 1 to day 3 of pregnancy, higher amounts of $\mathrm{Cu}-\mathrm{Zn}$ superoxide dismutase were present in the luminal lining as compared to the stromal regions (Figs. 3c, e, g), while on days 4, 5 and 6 uteri, the high SOD levels had shifted to the stromal parts of the uterus (Figs. 4a, e, g). This was clear when control sections were viewed, where the sites of high enzymic activity could not be completely inhibited by the concentration of diethyldithiocarbamic acid used (Figs. 3d, f, h; Figs. 4b, f, h).

The uterus from mice at 5:00 A.M. on day 5 showed a decreased amount of $\mathrm{Cu}$ $\mathrm{Zn}$ superoxide dismutase as was evident from the darker color of the entire uterine tissue. The $\mathrm{Cu}-\mathrm{Zn}$ superoxide dismutase activity seems to be more significantly lowered, at this time, in the endometrial lining, which is a site of attachment of the blastocysts. This is evident from the maximum amount of formazan formation in the endometrium (Figs. 4c, d).

\section{DISCUSSION}

Our results on the histochemical localization of superoxide dismutase in the ovary and uterus are in accordance with our earlier observed superoxide dismutase levels demonstrated biochemically (6). Our results showed high levels of $\mathrm{Cu}-\mathrm{Zn}$ SOD in the Graafian and ovulated follicles and corpora lutea during generation of high levels of $\mathrm{H}_{2} \mathrm{O}_{2}$ so as to make it available for peroxidase action during luteal steroidogenesis in order to synthesize progesterone $(5,7)$, a pre-requisite for implantation (4).

The specific absence of superoxide dismutase in the endometrial lining of the 

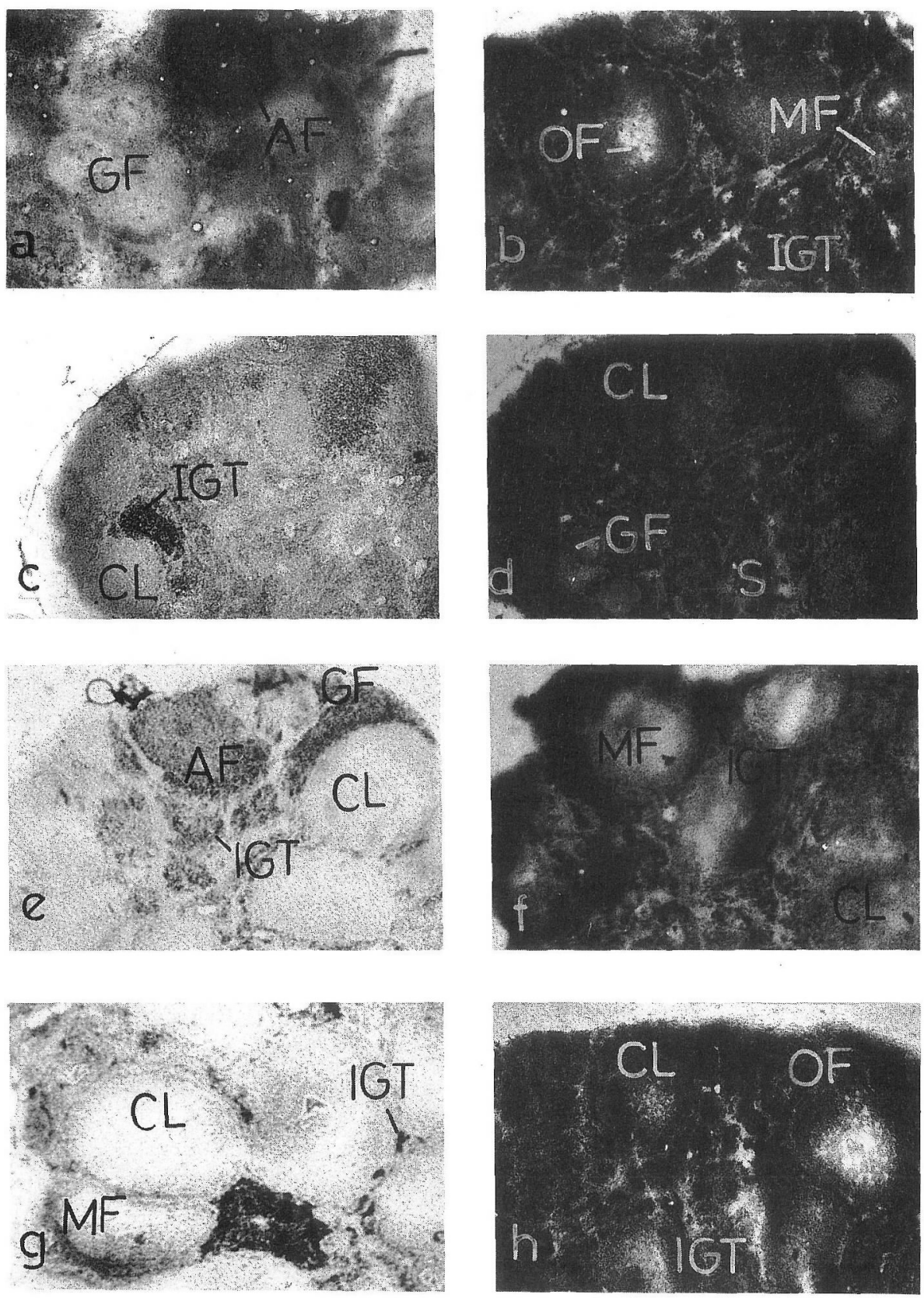

Figs. 1a-h. Photomicrographs (a, c, e and $\mathrm{g}$ ) of portions of mice ovary from mice at days $0,1,2$ and 3 exhibiting high enzymic activity in the growing GF and ovulated (OF) follicles and moderate activity in the corpora lutea (CL). Inhibition of the enzyme activity is seen in control sections (b, $\mathrm{d}, \mathrm{f}$ and $\mathrm{h}$ ). Interstitial gland tissue (IGT) and atretic follicles (AF) are devoid of the enzyme. MF: mature follicle, S: stroma. $\times 32$ 

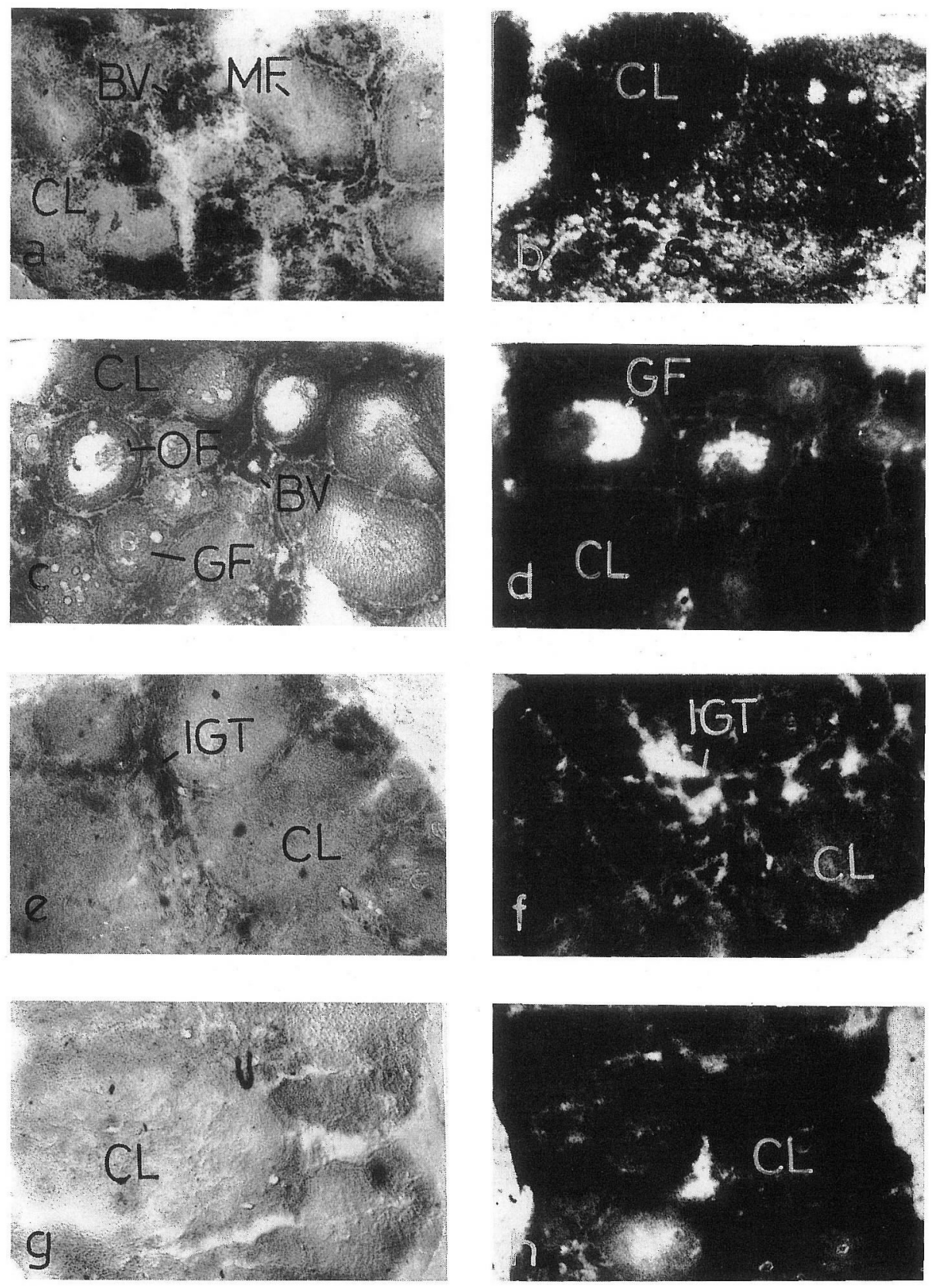

FIGs. 2a-g. Photomicrographs (a, c, e and g) of portions of ovary from mice at days 4, 5 (5:00 A.M.), 5 and 6 showing the presence of high superoxide dismutase activity in growing (GF) and ovulated (OF) follicles, corpora lutea (CL) and blood vessels (BV) which is specifically inhibited in the above mentioned regions in the control sections $(b, d, f$ and $h)$. Lack of enzyme activity is seen in the interstitial gland tissue (IGT) and atretic follicles (AF). MF: mature follicles, S: stroma. $\times 32$ 

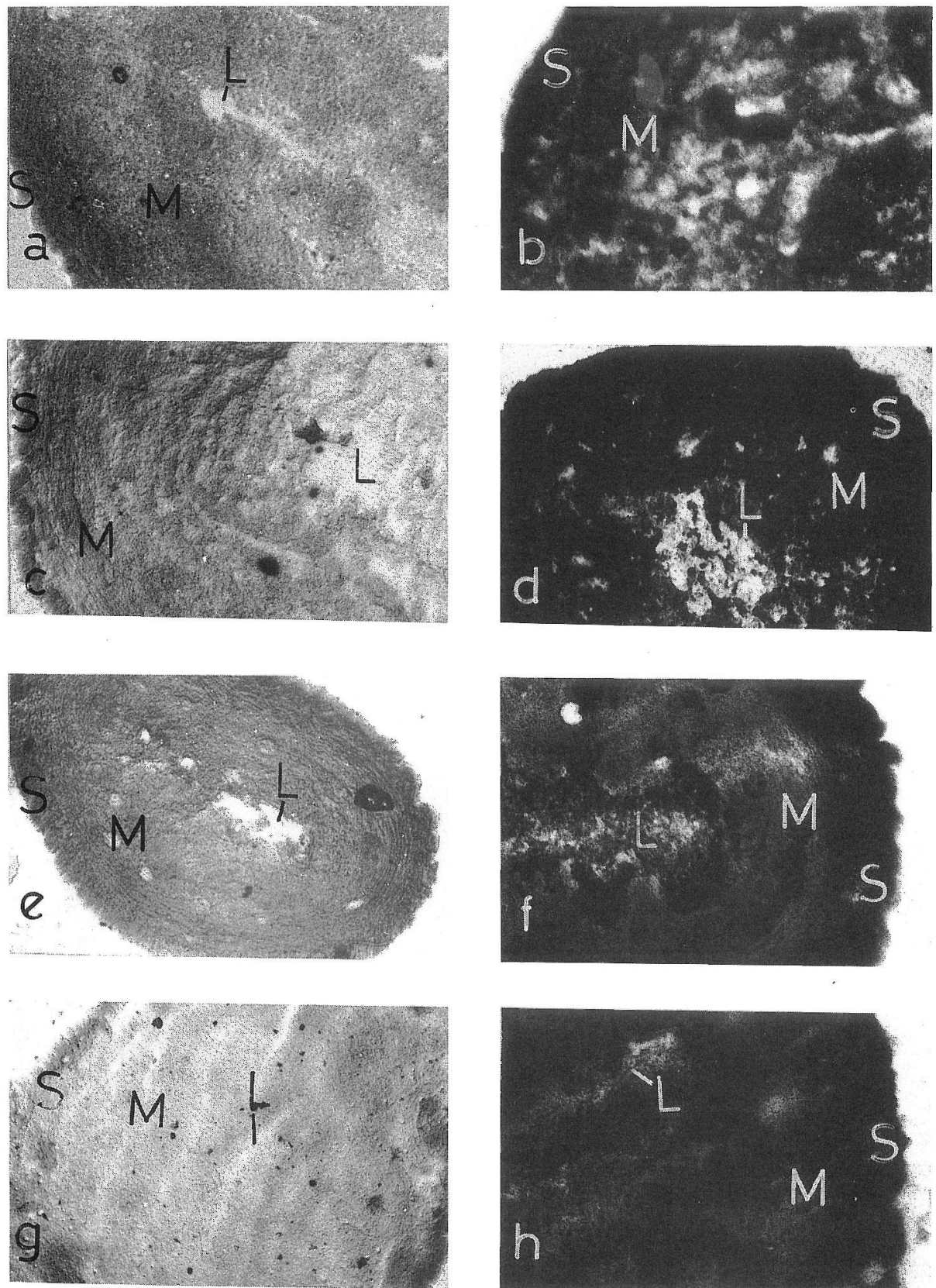

FIGs. 3a-h. A high amount of enzyme activity is observable in portions of mice uterus of days 0,1 , 2 and 3 of pregnancy ( $a, c$, e and $f$ ). This activity is inhibited in control sections (b, $d, f$ and $h$ ). S: serosa, M: myometrium, L: lumen. $\quad \times 32$ 

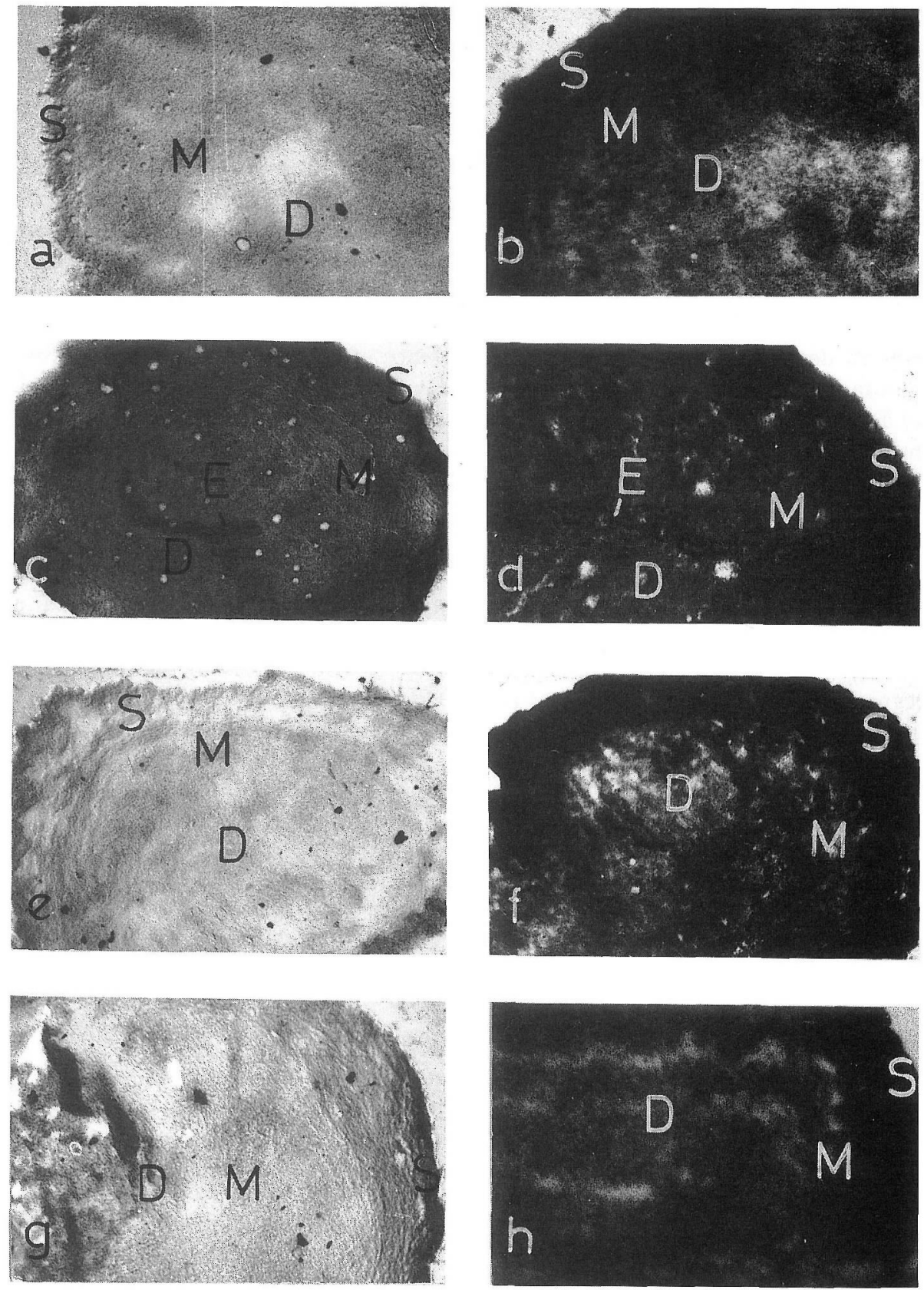

FIGs. 4a-h. A high superoxide dismutase activity is observable in the uterus portions from mice at days 4,5 and 6 of pregnancy (a, e and $\mathrm{g}$ ), while this enzyme activity is inhibited in control sections ( $b, f$ and $h$ ). A very low superoxide dismutase activity was observed in the entire uterine tissue of day 5 pregnant mice at 5:00 A.M (c). The endometrium (E) is completely devoid of the enzyme at this time as is evident from the dark color due to diformazan formation in the endometrium. The control preparation of this stage also is presented (d). S: serosa, M: myometrium, D: decidua. $\times 32$ 
uterus of the pregnant mouse early in the morning (5:00 A.M.) of Day 5 strengthens our hypothesis of the involvement of superoxide radical in implantation (6). This lack of superoxide dismutase might lead to localized accumulation/generation of superoxide radical, which would thereafter be involved in the permeability reactions during implantation.

A study of the uterine mitotic patterns in the rat indicates that the luminal epithelial cells undergo mitosis until midnight of day 3 , when strong mitotic activity then appears in the stromal cells (10). We propose that the $\mathrm{H}_{2} \mathrm{O}_{2}$ generated as a consequence of superoxide dismutase activity during day 1 to day 3 of pregnancy would be responsible for the mitotic activity, since $\mathrm{H}_{2} \mathrm{O}_{2}$ has been implicated as having a role in the regulation of normal cell division $(7,8)$. The switch over in the site of mitotic activity on day 4 can be explained by the presence of a higher amount of superoxide dismutase in the stromal region on day 4 to day 6 , except during the early morning of day 5 (5:00 A.M.), as opposed to its presence in the luminal lining on day 1 to day 3 . This is evident from control sections where regions containing higher levels of superoxide dismutase still show the negative staining pattern. This is probably due to the incomplete inhibition of the enzyme which is present in higher amounts, by the concentration of the enzyme inhibitor, diethyldithiocarbamic acid, used.

Thus, it seems that in a closely regulated sequence of events, the superoxide radical and superoxide dismutase play an important role in the act of implantation, both at the ovarian and at the uterine levels. In the ovary, they find their role in the synthesis of progesterone during extended luteal steroidogenesis at the time of early pregnancy. The superoxide radical-superoxide dismutase system also seems to induce increased mitosis in the uterus associated with the preparation of implantation.

\section{ACKNOWLEDGEMENT}

The financial assistance provided by Council of Scientific \& Industrial Research, New Delhi, India is thankfully acknowledged.

\section{REFERENCES}

1. Agrawal, P. and Laloraya, M. M.: Induction of peroxidase in corpora lutea of rat ovary by lutropin. Biochem. J. 166; 205-208, 1977.

2. Agrawal, P. and Laloraya, M. M.: Histochemical studies on the peroxidase localization in the rat ovary and uterus during various reproductive stages. Acta anat. 102; 94-101, 1978.

3. Agrawal, P. and Laloraya, M.M.: Ascorbate and peroxidase changes during pregnancy in albino rat and swiss mouse. Am. J. Physiol. 236: E386-E390, 1979.

4. Davies, I. J. and Ryan, K. J.: Comparative endocrinology of gestation. Vitams. Horm. 30; 223-279, 1972.

5. Laloraya, M., Kumar, G. P. and Laloraya, M. M.: Changes in the levels of superoxide anion radical and superoxide dismutase during the estrous cycle of Rattus norvegicus and induction of superoxide dismutase in rat ovary by lutropin. Biochem. Biophys. Res. Commun. 157; 146-153, 1988.

6. Laloraya, M., Kumar, G. P. and Laloraya, M. M.: A possible role of superoxide anion radical in the process of blastocyst implantation in Mus musculus. Biochem. Biophys. Res. Commun. $161 ; 762-770,1989$. 
7. Laloraya, M., Kumar, G. P. and Laloraya, M. M.: Histochemical study of superoxide dismutase in the ovary of the rat during the oestrous cycle. J. Reprod. Fertil. 86; 583-587, 1989.

8. Oberley, L. W., Oberley, T. D. and Buettner, G. R.: Cell division in normal and transformed cells: the possible role of superoxide and hydrogen peroxide. Med. Hyp. 7; 21-42, 1981.

9. Stockard, C. R. and Papanicolaou, G. N.: The existence of a typical oestrous cycle in the guinea-pig with a study of its histochemical and physiological changes. Am. J. Anat. 22; 225283, 1917.

10. Wu, J. T. and Chang, M. C.: The physiology of implantation and its inhibition by some agents. In Recent Advances in Fertility Regulation, ed. by C. C. Fen, D. Griffin and A. Woolman, Atar S. A., Geneva, 1981, pp. 177-195 